УДК 001.891:[004.921.78:005.921.-022.324-001.341]

DOI: $10.37026 / 2520-6427-2020-103-3-41-47$
Світлана IBАНОВА,

кандидат педагогічних наук,

завідувач відділу відкритих освітньо-наукових

інформачійних систем

Інституту інформаційних технологій

i засобів навчання НАПН Украӥни, м. Київ

Алла КІЛЬЧЕНКО,

науковий співробітник

Інституту інформаційних технологій

$i$ засобів навчання НАПН, м. Київ

\title{
МОНІТОРИНГ ВИКОРИСТАННЯ ВЕБСАЙТІВ ЗАКЛАДІВ ОСВІТИ ТА НАУКОВИХ УСТАНОВ ІЗ МОБІЛЬНИХ ПРИСТРӦ̈в ЗАСОБАМИ GOOGLE ANALYTICS
}

У статті досліджено проиедуру моніторингу використання вебсайтів закладів освіти та наукових установ із мобільних пристроїв за допомогою системи Google Analytics на прикладі вебресурсу електронної бібліотеки НАПН України. Проаналізовано процеси відвідування та використання иього сайту для з'ясування потреб і мотиваиії користувачів $з$ метою підвищення ефективності обслуговування, поліпшення контент-наповнення та збільшення його відвідуваності. Розглянуто використання сервісу Google Analytics як інструмента для збору, опрацюювання та аналізу статистичних показників наукових та освітніх вебсайтів задля поліпшення їх роботи.

Ключові слова: сервіс Google Analytics, вебсайт, аналітика, мобільні пристрої, електронна бібліотека, моніторинг, відкриті електронні інформаційно-аналітичні системи.

В статье исследована проиедура мониторинга использования вебсайтов учебных заведений и научных учреждений с мобильных устройств с помощью системы Google Analytics на примере вебресурса электронной библиотеки НАПН Украины. Проанализированы процессы посещения и использования этого сайта для выяснения потребностей и мотивации пользователей с изелью повышения эффективности обслуживания, улучшения контент-наполнения и увеличения его посешаемости. Рассмотрено использование сервиса Google Analytics как инструмента для сбора, обработки и анализа статистических показателей научных и образовательных вебсайтов с иелью улучшения их работьл.

Ключевые слова: сервис Google Analytics, вебсайт, аналитика, мобильные устройства, электронная библиотека, мониторинг, открытыле электронные информационно-аналитические системы.

The article examines the procedure for monitoring the use of websites of educational and research institutions from mobile devices using the Google Analytics system on the example of the web resource of the Electronic $\mathrm{Li}$ brary of the National Academy of Educational Sciences of Ukraine. The process of visiting and using this site to track the needs and motivations of users in order to increase the efficiency of service, improve the content and increase its traffic was tracked. The use of Google Analytics as a tool for collecting, processing and analyzing statistics of scientific and educational websites in order to improve their performance is considered. Traffic from PC and mobile device or tablet is compared. With the help of Google Analytics, you can learn in detail about the audience of users of the site by: language, age, gender, main interests, etc., ie demographics, geodata, location, etc. Google Analytics brand information on your phone or tablet helps you understand how to optimize this resource for different devices with different screen sizes and browser characteristics, so that the site is optimally configured on all major mobile devices. With Google Analytics reports, you can customize your site template for mobile owners so you don't lose visitors from your mobile traffic. If the web resource of educational and research institutions does not provide sufficient functionality for mobile users, it may affect its conversion, which is part of visits to the web resource, during which users have made a targeted action - visited a page, download material, etc. To increase the number of shared conversions, you need to improve the performance of your mobile devices and tablets. The main tasks of administrators of web resources of educational institutions and research institutions are to keep users on the site longer and provide easy interaction with the page to facilitate the implementation of conversion actions: call, registration, etc.

Key words: Google Analytics service, vebsite, analytics, mobile add-ons, electronic library, monitoring, open electronic information-analytical systems. 
В епоху цифровізації освітянам і вченим важливо мати прості та надійні механізми здійснення наукових зв'язків, відчувати себе частиною наукової спільноти. Тому стає необхідною наявність потужної й зручної платформи для реалізації і технічної підтримки комунікації, яка могла б використовуватися всіма працівниками та сприяла б вирішенню завдань, що стоять перед закладами й установами. Багатофункціональні можливості сучасних інформаційних технологій застосовуються для полегшення контактів між ученими, є додатковим механізмом наукового спілкування, обміну думками, ведення полеміки тощо [1].

Роль цифрових технологій у повсякденному житті набула неабиякого значення, адже для вирішення найрізноманітніших завдань усе більша кількість людей стає користувачами Інтернету. На початок 2020 р. населення планети становило 7,8 млрд людей, серед яких більше ніж половина $(4,54$ млрд осіб, за даними Internet World Stats (IWS)) це кількість користувачів Інтернету у світі (за рік зростання сягнуло 7 \%), а аудиторія соціальних мереж перевищила позначку в 3,8 млрд (за рік зросла на 9 \%). Майже 60 \% світового населення вже мають онлайн-доступ. Сьогодні понад 5,19 млрд осіб нашої планети користуються мобільними телефонами (здебільшого смартфонами), приріст яких за останній рік становить 124 млн (2,4\%) людей. Згідно зі статистикою Statcounter близько 53 \% усіх запитів в Інтернеті роблять саме 3 мобільних пристроїв, водночас $44 \%$ від усього світового вебтрафіку становлять комп'ютери.

В Україні також спостерігається зростання кількості користувачів Мережі. За даними Державної служби статистики, станом на 1 січня 2020 р. 25,68 млн жителів нашої країни є користувачами вебпростору, із них понад 19 млн осіб користуються мобільним інтернетом. Аудиторія соцмереж нараховує 13 млн українців, з яких 9,5 млн населення є користувачами мобільних телефонів.

Постановка проблеми. Зважаючи на відомості, наведені вище, власники вебресурсів освітніх i наукових установ стикаються 3 актуальними питаннями: яка статистика найбільш важлива для правильної контент-стратегії; які заходи вжити, щоб сайт використовувався ефективно та був популярним серед користувачів тощо. Зокрема фахівці SEO (Search Engine Optimization) значну кількість зусиль спрямовують на збір, опрацювання та аналіз статистичних даних вебресурсів, адже для дієвого поліпшення цих показників їх необхідно спочатку виміряти. Відповіді на ці питання дає вебаналіти$\kappa a$ - пряме відображення поведінки відвідувачів на вебресурсі [2].

Варто зауважити, що на сьогодні в галузі вітчизняної педагогіки існує недостатньо розроблених методик, рекомендацій із питань використання відкритих електронних інформаційно-аналітичних системи для наукових і науково-педагогічних працівників.

Аби отримати відомості щодо поведінки відвідувачів на сайті й зрозуміти основні напрями їхніх запитів, потрібно відстежувати та аналізувати різні показники вебаналітики, зокрема кількість відвідувань і користувачів, тривалість відвідування тощо. За допомогою цих відомостей можна коригувати контент вебсайтів та виявляти ділянки для покращення, вдосконалення, знаходження нових інструментів онлайн-просування сайту, його наповнення, інтерфейсу, тестування новітніх функціональних можливостей.

Зважаючи на означене вище, можемо стверджувати, що у всьому світі в середньому загальна кількість користувачів мобільних пристроїв $i$ планшетів перевищила кількість користувачів персональних комп'ютерів (десктопів), і тенденція до зростання продовжується. Тому потрібно налаштувати всі пристрої користувача для комфортного доступу зі зрозумілим інтерфейсом для взаємодії 3 вебресурсом. Власники вебсайтів можуть використовувати адаптивний вебдизайн, створювати декілька версій сайту або розробляти мобільний додаток, аби забезпечити комфортний інтерфейс для користувачів усіх пристроїв. Однак при цьому важливо проводити аналітику з десктопа і мобільного пристрою.

Упровадження Інтернету в галузь науки та освіти відкрило широкі можливості для їх розвитку у всьому світі, зокрема й в Україні. В умовах сьогодення $3 \mathrm{BO}$ та наукові установи мають власні електронні ресурси, такі як: сайти установ, інституційні репозитарії, курси дистанційного навчання, електронні бібліотеки, сайти наукових чи періодичних видань та ін. Ці електронні ресурси використовуються не лише для виконання представницьких і презентаційних функцій, але й допомагають професійній комунікації, надають цілісне уявлення щодо діяльності закладів та їх працівників. Водночас вони є потужним маркетинговим інструментом, що дозволяє проводити комплексне просування серед основних цільових аудиторій, тобто це спільна робота над внутрішніми й зовнішніми факторами, які впливають на ранжування пошуку, стимулюють попит на наукову продукцію, здійснюють їх реалізацію та ін. Використання цього каналу комунікації як основного стає все більш поширеною практикою, адже має низку вагомих переваг: можливість цілодобово працювати в онлайн-режимі, оперативність зміни змісту сторінок, покращення контенту вебресурсів, наявність зворотного зв'язку, прозорість середовища та ін. [3].

Тому важливим стає аналіз актуальності та ефективності використання вебсайту, який можна здійснити за допомогою різноманітних аналітичних сервісів, як-от: Spring Metrics, Woopra, Google Analytics, Clicky, Mint, Chartbeat тощо. Серед них найбільш популярною є безкоштовна система Google Analytics $(\partial а л i-G A)[5]-$ зручний засіб моніторингу відкритих електронних систем, за допомогою якого можна здійснювати збирання, опрацювання, зберігання та подання статистичних даних щодо відвідування сайтів, електронних бібліотек, блогів та інших ресурсів Інтернету.

Аналіз наукових досліджень і публікацій. Актуальним завданням сьогодення для освітян і науковців $€$ набуття знань, розвиток умінь та навичок щодо роботи $з$ відкритими електронними інформаційноаналітичними системами, збирання статистики, іiі опрацювання та аналіз для ефективного проведення освітньо-наукової діяльності.

Так, у 2008 р. американські вчені М. Сизик і С. Чоудхорі вперше дослідили й оцінили наявні 
електронні системи відкритого доступу, що використовувалися для підтримки педагогічних досліджень, зокрема наукових та освітніх. Проблемами з питань оптимізації сайтів, вебаналітики, конверсії тощо студіювали у своїх роботах такі зарубіжні вчені, як А. Блейк, А. Браун, М. Хасслер, А. Каушик, А. Косавич, Дж. Ледфорд, Р. Лукас, П. Ховей, Дж. Тейшейра, М. Тайлер, Дж. Віллінський та ін.

Питання використання відкритих інформаційно-аналітичних систем із метою підтримки наукових досліджень та аналізу дослідницької діяльності вчених і наукових установ знайшли відображення в публікаціях вітчизняних дослідників, серед яких В. Ю. Биков, В. Н. Бурков, О. Р. Гарасим, Г. М. Добров, О. І. Жабін, О. І. Жилінська, Є. О. Копанєва, Л. Й. Костенко, Т. Л. Новицька, Л. А. Лупаренко, О. А. Одуд, Т. В. Симоненко, О. М. Спірін, А. В. Яцишин та ін. Також означена проблема розглядалася й у попередніх публікаціях авторів даної статті.

Мета статті - проаналізувати особливості моніторингу використання вебсайтів освітніх і наукових установ із мобільних пристроїв за допомогою системи Google Analytics.

Виклад основного матеріалу. Співробітниками Інституту інформаційних технологій і засобів навчання НАПН України (далі - Iнститут) за допомогою служби GA 32011 р. щоквартально та за звітний рік проводиться аналіз (моніторинг) у вигляді звітних аналітичних матеріалів щодо використання вебресурсів установи: електронної бібліотеки НАПН України (http://lib.iitta.gov.ua), електронного наукового фахового видання «Інформаційні технології і засоби навчання» (http://journal.iitta.gov.ua) та сайту Інституту (http://iitlt.gov.ua) з метою реалізації завдань щодо надання інформаційно-методичної підтримки науково-педагогічним дослідженням та формування позитивного іміджу закладу. Аналіз здійснюється за низкою основних показників: поведінкою відвідувачів на сайті, демографією відвідувачів, технологіями відвідування сайту, мобільними пристроями, трафіком та ін. [3].

Після налаштування сервісу GA для моніторингу використання освітньо-наукових вебресурсів Інституту з'явилася можливість збирати та аналізувати відомості щодо відвідуваності сайтів, кількості переглядів сторінок тощо, а також дізнаватися, зміст яких освітньо-наукових матеріалів призводить до найбільшого числа відвідувань сайтів, які наукові ресурси є найбільш актуальними, оцінити трафік вебсайтів та багато іншого. Важливим $є$ те, що аналітика допомагає виявити, звідки прийшов користувач, що дає можливість зрозуміти, як його залучити до повернення на вебсайт. Дані моніторингу відображаються у вигляді графіків і діаграм, за допомогою яких можна легко налаштувати й оптимізувати сайт, зробивши перебування на ньому комфортним і корисним для користувача.

У 2012 р. була запущена система GA для мобільних додатків для здійснення аналітики через SDK для Android та iOS. Сьогодні в більшості аудиторії популярності набув перехід до використання смартфонів, планшетів та інших мобільних пристроїв. Завдяки цьому звіту можна проаналізувати кількість користувачів, які заходять на вебресурс iз десктопу, планшету чи мобільного пристрою [4].
Із 2015 р. відсутність адаптованої під мобільні пристрої версії сайту впливає на рейтинг пошукової системи Google.

За умов, якщо користувач отримає неадаптований сайт, то показник відмов зросте. При цьому користувач із меншою ймовірністю зробить конверсію та 3 більшою ймовірністю повернеться назад до результатів пошуку, тобто піде до іншого вебресурсу. Важливо відслідковувати, як мобільні та планшетні користувачі взаємодіють із вебресурсом для виявлення та розв'язання різноманітних проблем. GA дозволяє відокремити трафік із десктопа, мобільного пристрою та планшета, аби мати можливість переглядати важливу статистику після правильного налаштування відстеження аналітики.

Порівняння трафіку з десктопа і мобільного пристрою або планшета. У системі GA можна оглянути різні категорії пристроїв, якщо спочатку перейти на вкладку Звіти, а потім - Аудиторія> Мобільні приcтроі> Огляд. У вкладці Огляд видно, як продуктивність мобільного і планшетного трафіку порівнюється 3 продуктивністю десктопа. Типова ситуація мобільні пристрої та планшети отримують великий обсяг трафіку, однак він конвертує менше. Звичайно для кожного сайту ситуація відрізняється, але тенденція зберігається.

Найшвидший спосіб відстежити корисну статистику - візуальний розподіл інформації, яка частка сеансів, цілей або доходів надійшла 3 кожного джерела. Найважливіше, що можна тут побачити - це розподіл між кожною метрикою (показником). Розглянемо одну з найбільш корисних функиій сервісу $G A$ - можливість побачити, яка кількість користувачів відвідує вебресурс за допомогою різних мобільних пристроїв: планшетів, смартфонів тощо на прикладі сайту електронної бібліотеки НАПН України (далі - ЕБ НАПН України).

Мобільний пристрій - це переносний електронно-обчислювальний пристрій, що здатний приймати, відображати, зберігати, опрацьовувати й передавати інформацію, призначений насамперед для перегляду вебсторінок і роботи з вебсервісами.

GA дає можливість відстежити, яким пристроєм користуються відвідувачі. На рисунку 1 подано огляд користувачів, що відвідали сайт ЕБ НАПН України впродовж січня-травня 2020 р., з якого видно, що кількість користувачів десктопів становить 21,62 тис. осіб, мобільних пристроїв (mobile) - 9,86 тис., а планшетів (tablet) - 0,36 тис., тобто загальна кількість користувачів десктопів дорівнює 69 \%, mobile тa tablet - $31 \%$, однак тенденція до зростання використання останніх продовжує збільшуватися. Також можна побачити, що загальна кількість користувачів з усіх пристроїв значно зросла під час карантину, а у квітні 2020 р. сягнула позначки майже 1500 чоловік.

Інструментарій GA можна використовувати для того, щоб дати швидку оцінку всім діям, які відбуваються на вебресурсі. Якщо ж потрібно внести фактичні зміни на сайті, необхідно зробити кількісну оцінку мобільного пристрою та планшета.

Порівняльний звіт демонструє, як працює метрика відносно середнього значення показників сайту, що дає змогу виокремити кращі та гірші випадки. 


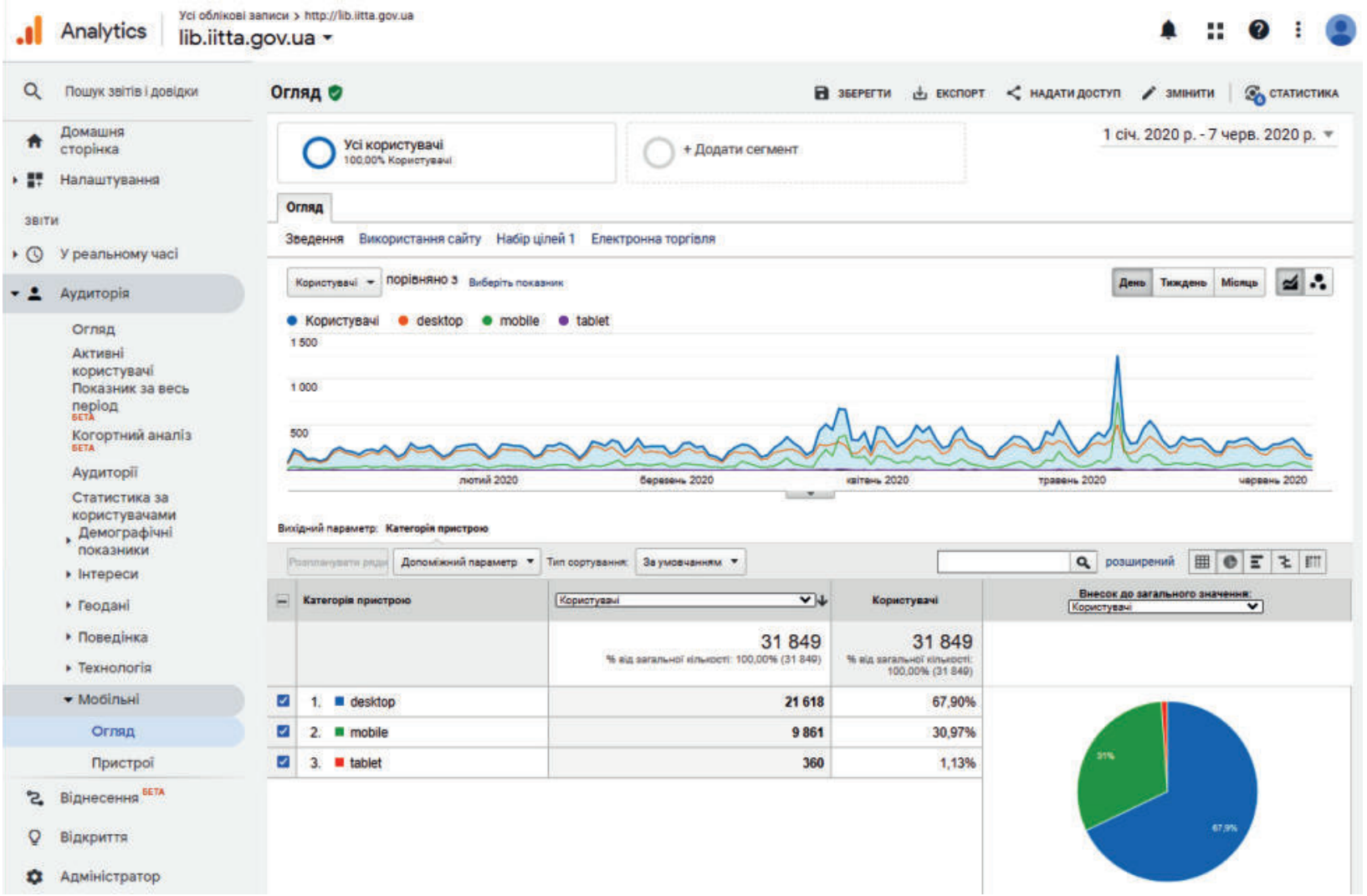

Рис. 1. Оаляд користувачів сайту ЕБ НАПН Украйни впродовж 2020 р.

Цю інформацію доцільно використовувати під час перегляду показників продуктивності за сеанс, зокрема таких, як коефіцієнт конверсії електронної комерції або середня тривалість сеансу. Із порівняльного звіту за показником середньої тривалості перебування відвідувачів сайту ЕБ НАПН України протягом 2020 р. (див. рис. 2) видно, що коли користувачі заходять на сайт із десктопу, то перебувають на ньому довше, ніж тоді, коли використовують мобільні або планшетні пристрої.

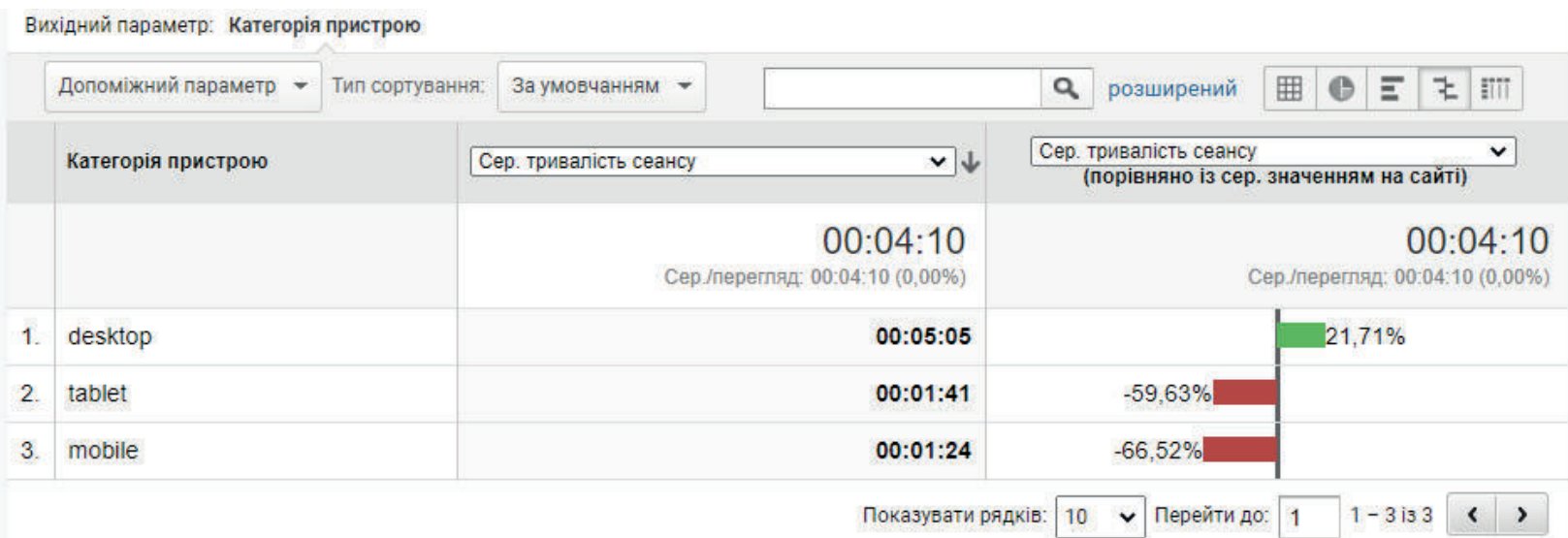

Рис. 2. Порівняльний звіт за показником середньої тривалості перебування користувачів сайту ЕБ НАПН України протягом 2020 р.

Означений звіт дає змогу відстежити середні показники взаємодії вебресурсу з кожним користувачем. Водночас для більшості сайтів важлива не кількість відвідувачів із різних пристроїв, а їх конвертація та взаємодія на ньому.

Створення звітів щодо пристроїв, призначених для користувача. Мобільний трафік у GA можна сегментувати, використовуючи призначений для користувача звіт із вкладки Налаштування у верхній частині Analytics. Цей звіт може бути застосований для ретельного аналізу даних різними способами. Наприклад, можна дізнатися, як працює мобільний трафік на будь-яких цільових сторінках.

Система GA дозволяє зробити звіт за кожним відвідувачем сайту або користувачем додатку: коли він вперше зайшов на сайт, звідки потрапив на нього, який застосовує пристрій, яка частота відвідування та ін. За допомогою сервісу також детально можна дізнатися відомості щодо аудиторії користувачів сайту за мовою, віком, статтю, основними інтересами 
тощо, тобто отримати демографічні показники, геодані, місиеположення тощо. На рисунку 3 відображено демографію відвідувачів сайту ЕБ НАПН України 3 мобільних пристроїв за різними країнами впродовж 2020 р. Зі статистичних даних цього звіту видно, що iз 83 країн найбільше користувачів було з України 8,37 тис., друге місце займають США - 1,41 тис., а третє - Росія 3 кількістю 0,05 тис. відвідувачів.
Таку ж демографію можна простежити за містами цих країн. На рисунку 4 подано демографію відвідувачів сайту ЕБ НАПН України з мобільних пристроїв за містами протягом січня-травня 2020 р. Як бачимо з моніторингу звіту, із 793 міст найбільше користувачів було з Києва - 2,92 тис., при цьому на другому місці - місто Ірвін (штат Каліфорнія США) 0,84 тис. осіб.

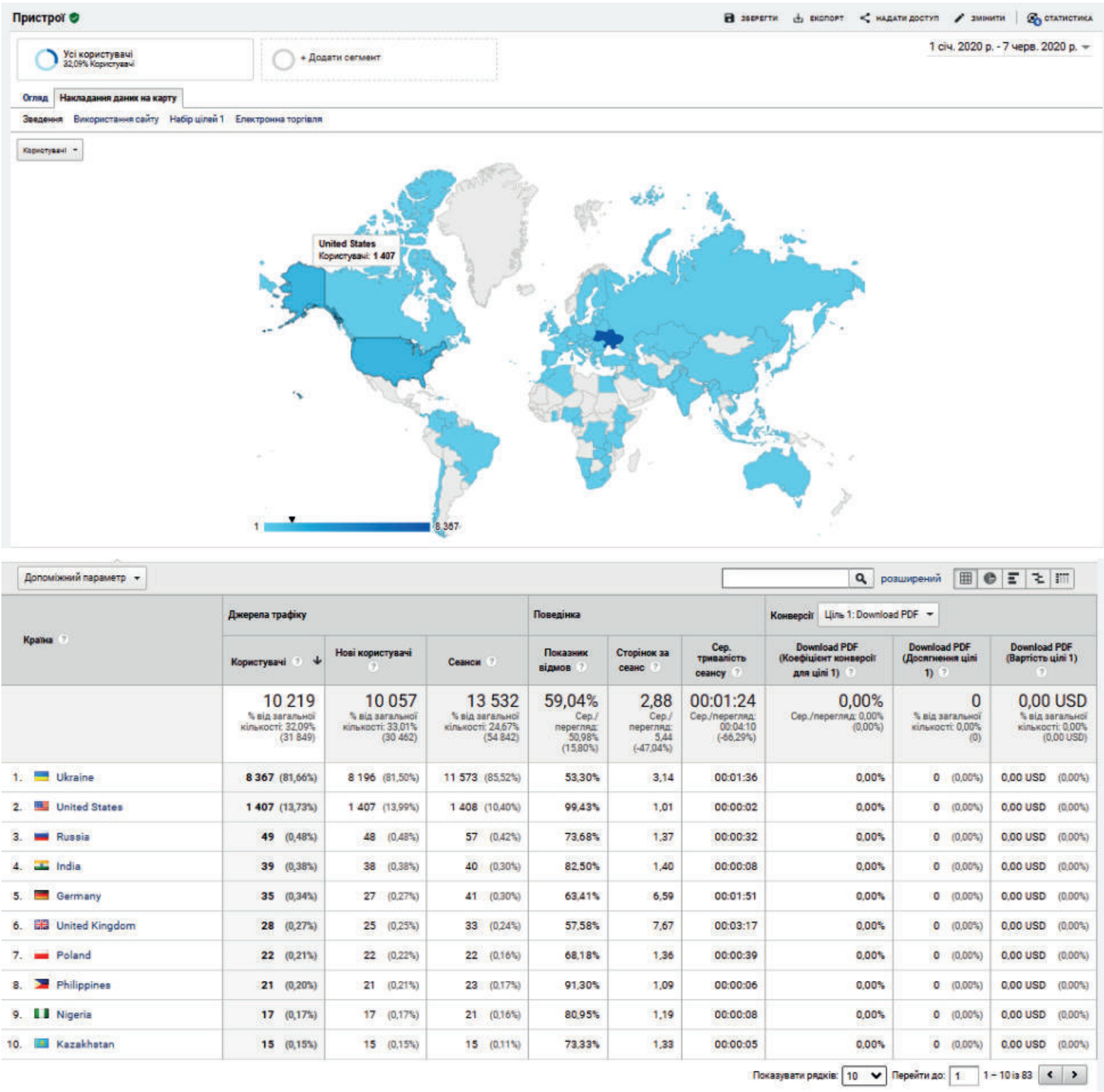

Рис. 3. Демографія відвідувачів сайту ЕБ НАПН Украӥни з мобільних пристроїв за краӥною протягом січня-травня 2020 р.

Відомості GA за брендом телефону або планшету (див. рис. 4) допомагають зрозуміти, як оптимізувати означений ресурс під різноманітні девайси, що відповідно мають різні розміри екрана та характеристики браузера, аби сайт був оптимально налаштованим на всіх основних мобільних пристроях.

Як бачимо на рисунку 5, основними брендами мобільних пристроїв користувачів сайту ЕБ НАПН України за містом протягом січня-травня 2020 р. є Apple, Xiaomi, Samsung, Huawei, частка яких становить понад 87 \% від усіх інших мобільних телефонів та планшетів.
Розглянемо статистичні відомості щодо відвідування сайту ЕБ НАПН України з мобільних пристроїв упродовж 2012-2020 рр. станом на 07.06.2020 p.:

- мобільні пристрої (сеанси) - 188319 (від 363 у 2012 р. до 93903 у 2019 р.);

- дані про мобільний пристрій - 1779 (від 59 у 2012 р. до 1178 у 2019 р.);

- мобільні пристрої (за країнами) - 119 (від 12 у

2012 р. до 97 у 2019 р.);

- мобільні пристрої (за містами) - 1290 (від 42 у 2012 р. до 717 у 2019 р.). 


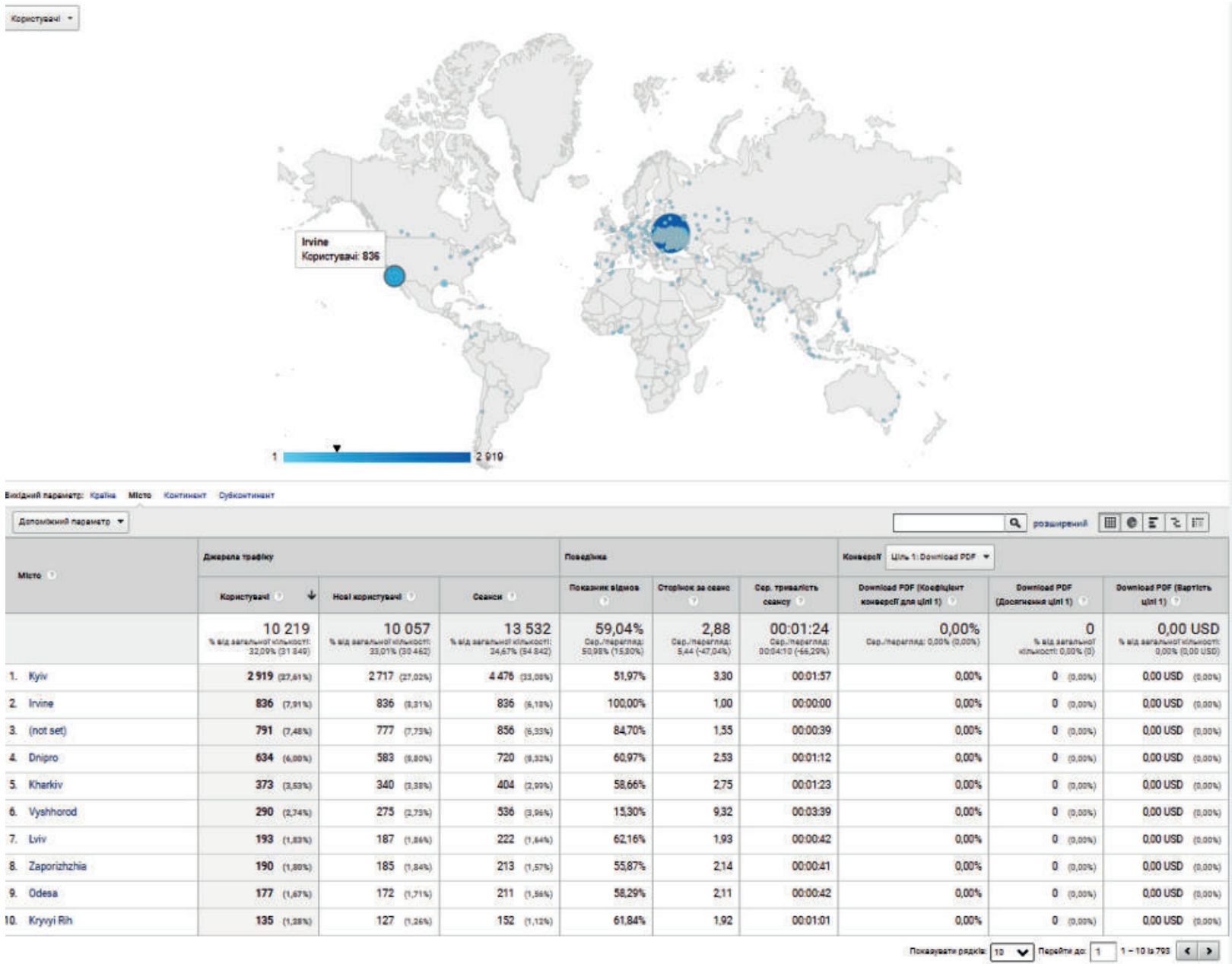

Рис. 4. Демографія відвідувачів сайту ЕБ НАПН України з мобільних пристроїв за містом протягом січня-травня 2020 p.

\begin{tabular}{|c|c|c|c|c|c|c|c|c|c|c|c|}
\hline \multirow{3}{*}{ - } & \multirow[b]{2}{*}{ Бренд мобільного пристрою ? } & \multicolumn{3}{|l|}{ Awepena трафікy } & \multicolumn{3}{|l|}{ Поведінха } & \multicolumn{4}{|c|}{ Koнверсій L Liль 1: Download POF - } \\
\hline & & $\frac{\text { Kopuotyeavi }}{7} \downarrow$ & $\begin{array}{c}\text { Нові } \\
\text { кориотувачi } \\
?\end{array}$ & Сеанси 7 & $\begin{array}{l}\text { Показник } \\
\text { відмов ? }\end{array}$ & $\begin{array}{c}\text { Cropinoк } \\
\text { a саеанe } \\
?\end{array}$ & $\begin{array}{l}\text { Cep. } \\
\text { триеаліог } \\
\text { сеансу } ?\end{array}$ & 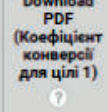 & $\begin{array}{l}\text { Download } \\
\text { PDF } \\
\text { (Aоскинения } \\
\text { чіini 1) } 3\end{array}$ & $\begin{array}{r}\text { Downloe } \\
\text { (Bapriore } \\
?\end{array}$ & $\begin{array}{l}\text { d PDF } \\
\text { uini 1) }\end{array}$ \\
\hline & & $\begin{array}{r}10219 \\
\text { s від загапьної } \\
\text { кількості: } \\
32,09 \%(31849)\end{array}$ & 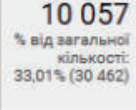 & $\begin{array}{r}13532 \\
\text { s від эaranьної } \\
\text { кількості: } \\
24,67 \% \text { (54 842) }\end{array}$ & $\begin{array}{r}59,04 \% \\
\text { Cep// } \\
\text { neperna: } \\
50,98 \% \\
(15.80 \%)\end{array}$ & $\begin{array}{r}2,88 \\
\text { Cep/ } \\
\text { nepersf, } \\
5,44 \\
(-47,044)\end{array}$ & $\begin{array}{r}00: 01: 24 \\
\text { Cepp./nepernaf } \\
00: 0410 \\
(-66.294)\end{array}$ & $\begin{array}{r}0,00 \% \\
\text { Cep/ } \\
\text { nepernaf } \\
0.00 \% \\
(0,005)\end{array}$ & 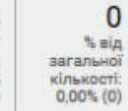 & 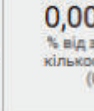 & $\begin{array}{l}\text { USD } \\
\text { aranbioil } \\
\text { riti. } 0.00 \% \\
.00 \text { USD) }\end{array}$ \\
\hline ש & 1. Apple & $3071(29,93 \%)$ & $3036(30,195)$ & $3552(26,25 \mathrm{~s})$ & $80,24 \%$ & 1,70 & $00: 00: 43$ & $0,00 \%$ & $0(0.004)$ & 0,00 USD & $(0.00 \mathrm{~N})$ \\
\hline च & 2. Xiaomi & $2755(26,85 \%)$ & $2695(26,80 \%)$ & $3729(27.56 \%)$ & $45,91 \%$ & 3,98 & 00:01:45 & $0,00 \%$ & $0(0,00 \%)$ & 0,00 USD & $(0,00 \mathrm{~s})$ \\
\hline च & 3. Samsung & $2176(21,20 \%)$ & 2118 (21,06\%) & $3100(22,91 \%)$ & $53,74 \%$ & 3,01 & 00:01:34 & $0,00 \%$ & $0(0,00 \%)$ & 0,00 USD & $(0,008)$ \\
\hline ఐ & 4. Huawei & $942(9,18 \%)$ & 920 (9.15\%) & 1438 (10.63\%) & $48,12 \%$ & 3,10 & 00:01:58 & $0,00 \%$ & $0(0.00 \%)$ & 0,00 USD & $(0.00 \%)$ \\
\hline (a & 5. Meizu & $262(2,55 \%)$ & $254(2,53 \%)$ & $356 \quad(2,63 \%)$ & $64,89 \%$ & 2,04 & 00:01:08 & $0,00 \%$ & $0(0,00 \%)$ & 0,00 USD & $(0.00 \%)$ \\
\hline (a & 6. (not set) & $207(2,02 \%)$ & 203 (2,02\%) & $273(202 \%)$ & $66,30 \%$ & 2,16 & 00:01:03 & $0,00 \%$ & $0(0,00 \%)$ & 0,00 USD & $(0,005)$ \\
\hline a & 7. Lenovo & 165 (1,61\%) & 161 (1.60s) & $190(1,40 \mathrm{~s})$ & $62,63 \%$ & 2,23 & $00: 01: 25$ & $0,00 \%$ & $0(0.00 \mathrm{t})$ & 0,00 USD & $(0,00 \mathrm{~N})$ \\
\hline 단. & 8. Sony & $72(0,70 \%)$ & 71 (0,71s) & 138 (1.02\%) & $50,72 \%$ & 3,73 & $00: 02: 07$ & $0,00 \%$ & $0(0.005)$ & 0,00 USD & $(0,00 \mathrm{v})$ \\
\hline$\square$ & 9. Nokia & 69 (0,674) & $67(0,679)$ & 90 (0.67\%) & $66,67 \%$ & 4,09 & $00: 02: 04$ & $0,00 \%$ & $0(0,00 \Omega)$ & 0,00 USD & $(0,00 \mathrm{~s})$ \\
\hline ㅁ & 10. Motorola & $57(0,56 \%)$ & 55 (0,55\%) & $74 \quad(0,55 \%)$ & $60,81 \%$ & 3,82 & $00: 02: 13$ & $0,00 \%$ & $0(0,00 \%)$ & 0,00 USD & $(0,00 \%)$ \\
\hline
\end{tabular}

Рис. 5. Відомості за брендом телефону або планшету відвідувачів сайту ЕБ НАПН Украӥни за містом протягом січня-травня 2020 p. 
Із порівняльного аналізу отриманих даних за 2012 р. та 2019 р. видно, що кількість сеансів користувачів із мобільних пристроїв за цей період збільшилася із 0,36 тис. до 93,90 тис. сеансів, тобто майже у 260 разів, а кількість моделей мобільних пристроїв зросла майже у 20 разів - від 59 до 1178. Також кількість країн, з яких заходили відвідувачі сайту, збільшилася з 12 до 97, тобто більше ніж у 8 разів, а географія міст зросла в понад 17 разів - із 42 до 717.

У цьому розділі можна побачити, з якої країни зайшли відвідувачі сайту та якою мовою їм більш зручно читати замітки. Іноді, якщо кількість таких відвідувачів значно підвищується, для залучення більшої кількості користувачів до вебресурсу потрібно створити версію сайту іншою мовою.

Якщо вебресурс не надає достатніх функціональних можливостей для користувачів мобільних пристроїв, це може вплинути на його конверсію, що $\epsilon$ часткою відвідувань вебресурсу, в процесі яких користувачі вчинили цільову дію - відвідали певну сторінку, завантажили матеріал тощо.

Таким чином, сервіс GA допомагає відстежити, як із часом сайт ЕБ НАПН України стає доступним і потужним для все більшої кількості мобільних пристроїв. Дані звітів сервісу GA щодо відвідувачів сайту, їх тематичної спрямованості, що викликає зацікавлення, а також кількість часу перебування на вебресурсі, дають змогу виконати роботи 3 підвищення рівня конверсії, тобто налаштувати вебресурс таким чином, щоб користувачі затримувалися на сайті триваліший час, переглядали його сторінки та ін. GA дає можливість дізнатися, якими пристроями користуються відвідувачі, що допомагає пристосувати шаблон сайту для власників мобільних пристроїв, планшетів, смартфонів, щоб не втрачати відвідувачів із мобільного трафіку.

Досвід і способи взаємодії з вебресурсом на мобільних пристроях та планшетах можуть різнитися між собою. Три типи пристроїв використовуються в різних місцях у різний час. Наприклад, користувач мобільного телефону може швидко переглядати сайт, перебуваючи в громадському транспорті. Водночас користувач планшета може переглядати вебсайт, одночасно дивлячись телевізор удома. Цей огляд надає реальну картину взаємодії з користувачами.

Підвищення продуктивності мобільних пристроїв $i$ планшетів: за умов поліпшення продуктивності мобільних пристроїв і планшетів можна значно збільшити кількість спільних конверсій.

Основні завдання адміністраторів вебресурсів закладів освіти і наукових установ полягають у тому, щоб довше затримати користувачів на сайті та забезпечити просту взаємодію зі сторінкою для полегшення виконання конверсійних дій: дзвінка, реєстрації тощо.

Деякі ділянки на вебсайті можуть не функціонувати належним чином на мобільних або планшетних пристроях у зв'язку з низкою причин: віджети не підтримуються на мобільному пристрої (наприклад, Flash-відеоплеєри не працюють на iPhone); неінтерактивні вікна, що спливають, не дають користуватися сайтом на мобільному екрані; мінітекстові посилання або зображення кнопок на маленькому дисплеї $€$ неінтерактивними; елементи сайту перекривають один одного (неінтерактивний контент).
Більшість вебсайтів мають понад 50 \% сукупного мобільного і планшетного трафіку. Тому важливо зрозуміти причини гальмування процесу і з'ясувати, яким чином налаштувати вебсайт задля його поліпшення. Також необхідно порівняти коефіцієнт до i після конверсії для різних пристроїв.

Висновки. Отже, застосування безкоштовного мегапотужного сервісу GA є важливим для організації ефективної роботи вебресурсів закладів освіти та наукових установ. Аналітична система GA допомагає провести якісний моніторинг та аналіз вебсайту, визначити ступінь відповідності сайту поставленим цілям, оцінити кількісні та якісні характеристики трафіку, виявити проблеми й знайти потенціал для збільшення конверсії сайту та багато іншого.

Таким чином, метою моніторингу використання вебресурсів наукових установ, ЗВО тощо в галузі освіти і науки за допомогою системи GA $є$ відстеження процесів відвідування й використання ресурсів та підвищення ефективності розробки й обслуговування цих сайтів для формування їх позитивного іміджу. GA дає можливість дізнатися, якими пристроями користуються відвідувачі; допомагає відстежити, як із часом вебресурси стають доступними для все більшої кількості мобільних пристроїв та поліпшити їх роботу; сприяє пристосуванню шаблона сайту для власників мобільних пристроїв таким чином, щоб не втрачати відвідувачів із мобільного трафіку.

Сервіс GA постійно оновлюється та доопрацьовується, що надає потужні інструменти цифрової аналітики вебсайтам закладів освіти й наукових установ. Крім того, аналітичну систему GA використовує понад 29 млн провідних вебсайтів усього світу, зокрема й українських - більше як 330 тис.

\section{СПИСОК ВИКОРИСТАНОЇ ЛІТЕРАТУРИ}

1. Іванова С. М., Яцишин А. В., Кільченко А. В. Напрями використання цифрових науково-освітніх систем для розвитку інформаційно-дослідницької компетентності наукових і науково-педагогічних працівників. Інформаційні технології в освіті та науці : зб. наук. праць Міжнар. наук.-практ. конф., м. Мелітополь, 13-14 черв. 2019 р. Мелітополь : Мелітопольський держ. пед. університет ім. Б. Хмельницького, 2019. С. 339-343.

2. Навчальний курс вебпроектування. URL: www. victoria.lviv.ua/library/students/wp/lab3.html (дата звернення: 06.06.2020).

3. Шиненко М. А., Іванова С. М., Кільченко А. В., Лабжинський Ю. А. Використання сервісу Google Analytics для моніторингу сайту наукової установи. Звітна наук. конф. ІІТЗН НАПН України : матеріали наук.-практ. конф., присвяч. 20-річчю ІІТЗН НАПН України, м. Київ, 20 лют. 2019 р. Київ : ІІТЗН НАПН України, 2019. С. 91-109. URL: http://lib.iitta.gov. ua/715956/ (дата звернення: 05.06.2020).

4. Burby J., Brown A., the WAA Standards Committee. Web Analytics Definitions - Version 4.0. Web Analytics Association. 2007. August 16. 34 p.

5. Google Analytics. URL: http://www.google.com/ analytics (дата звернення: 07.06.2020).

Дата надходження до редакиіï: 11.06.2020 p. 